\title{
Modlitwa błagalna \\ w świetle tajemnicy Opatrzności Bożej
}

Ks. prof. dr hab. JAN DANIEL SzczUREK

Uniwersytet Papieski Jana Pawła II w Krakowie

„Czy też Pan jest rzeczywiście wśród nas, czy nie?” (Wj 17, 7). To prowokacyjne pytanie jest zadawane do dziś. Przy wodach Meriba Bóg odpowiedział, dając ludowi wodę ze skały. Równocześnie jednak napiętnował jego postawę jako kuszenie: „kłócili się Izraelici i wystawiali Pana na próbę” (Wj 17, 7).

Postępująca sekularyzacja i coraz mniej skrywana niechęć, a nawet wrogość wobec Kościoła sprawiają, że świadomość obecności Boga w świecie coraz bardziej zanika. Człowiek współczesny żyje tak, jakby Boga nie było, przypomniał to św. Jan Paweł II w Krakowie podczas homilii na Błoniach (18 sierpnia 2002). Takie życie oznacza również zaniechanie modlitwy, a w konsekwencji zdanie się wyłącznie na własne, ludzkie siły, co z kolei nierzadko prowadzi do frustracji.

Pomocą w wyjściu ztrudnej sytuacji egzystencjalnej jest przywrócenie świadomości ciągłej obecności i działania Boga w naszym świecie poprzez modlitwę i zaufanie Opatrzności Bożej. Dlatego pragnę zaprosić do refleksji nad 
tajemnicą Opatrzności Bożej i nad miejscem naszej modlitwy w jej zrządzeniach. Nasze teoretyczno-teologiczne dociekania zostaną poparte praktycznym przykładem z życia bł. matki Marii Angeli (16 maja 1825 - 10 października 1899), założycielki Zgromadzenia Sióstr Felicjanek, i jej córek duchowych.

\section{Modlitwa błagalna}

Z nauki Katechizmu Kościoła katolickiego wiemy, że są cztery rodzaje modlitwy (por. KKK 2098): modlitwa uwielbienia, modlitwa dziękczynna, modlitwa przebłagalna i modlitwa prośby (błagalna). Dlatego, jak wyjaśnia dalej Katechizm: „modlitwa jest niezbędnym warunkiem posłuszeństwa przykazaniom Bożym. "Zawsze (...) [trzeba] się modlić i nie ustawać» (Łk 18, 1)” (KKK 2098). Według św. Augustyna (zm. 430) w modlitwie dochodzi do spotkania Bożego i naszego pragnienia z ludzkim pragnieniem, bo „Bóg pragnie, abyśmy Go pragnęli” (KKK 2560)ํ․ Z kolei według św. Jana Damaceńskiego (zm. ok. 749) „modlitwa jest wzniesieniem duszy do Boga lub prośbą skierowaną do Niego o stosowne dobra"2.

Katechizm poświęca wiele uwagi modlitwie, w tym także modlitwie prośby. „Nowotestamentowe słownictwo wyrażające błaganie jest bogate wodcienie znaczeniowe i oznacza: prosić, żalić się, wołać natarczywie, wzywać,

${ }^{1}$ Por. św. Augustyn, De diversis quaestionibus octoginta tribus 64, 4 (PL 40, kol. 56).

2 Św. Jan Damasceński, De fide orthodoxa 3, 24 (PG 94, kol. 1089 D, za: KKK 2559). 
podnosić głos, krzyczeć, a nawet «walczyć w modlitwie» (por. Rz 15, 30; Kol 4, 12 [gr. ả $\gamma \omega v i ́\left({ }_{0} \mu \alpha\right.$ ])" (KKK 2629). Starotestamentalnym przykładem takiej modlitwy-walki jest całonocna walka patriarchy Jakuba z Kimś tajemniczym, dającym ostatecznie błogosławieństwo (Rdz 32, 25-31; KKK 2573). „Najbardziej jednak zwyczajną formą błagania, ponieważ najbardziej spontaniczną, jest prośba" (KKK 2629), poprzez którą wyrażamy świadomość naszej zależności od Boga jako naszego Stwórcy i Zbawcy. Modlitwa jest więc zmaganiem się. Jest to zmaganie się $\mathrm{z}$ własną słabością, z wątpliwościami odnośnie do bycia wysłuchanym, z pytaniem o własne możliwości działania, z poczuciem osobistej bezsilności i upokorzenia, z ludzką beznadziejnością podważającą zaufanie Bogu, z lękiem o przyszłość. Wyjątkowym przykładem biblijnym takiej wewnętrznej walki podczas modlitwy prośby jest niewątpliwie modlitwa Pana Jezusa w Ogrojcu (Mk 14, 34-36), zanoszona do Ojca „z głośnym wołaniem i płaczem" (Hbr 5, 7).

Wobec tego powstaje pytanie, na ile tak usilna modlitwa prośby może wpłynąć na zmianę Bożych postanowień, Bożej woli. Świadectwa Starego Testamentu na ten temat zdają się sugerować możliwość takiej zmiany. Gdy Mojżesz uporczywie wstawiał się do Boga za lud, który cześć boską oddawał złotemu cielcowi, wówczas ,to Pan zaniechał zła, jakie zamierzał zesłać na swój lud" (Wj 32, 14; por. Ps 106, 23). Dawid żywił nadzieję na zmianę Bożych postanowień w stosunku do swego syna, którego urodziła mu Batszeba. Modlitwą bowiem i postem chciał wyprosić dla niego uzdrowienie, myśląc sobie: „Kto wie, może Pan nade mną się ulituje i dziecko będzie żyło?” (2 Sm 12, 22). Z kolei prorok 
Jeremiasz zapowiada możliwość zmiany Bożych zamiarów: „Teraz więc zmieńcie swoje postępowanie i swoje uczynki, słuchajcie głosu Pana, Boga waszego; wtedy ogarnie Pana żal nad nieszczęściem, jakie postanowił przeciw wam" (Jr $26,13)$. Z podobną zmianą mamy do czynienia w przypadku Niniwy, gdy w odpowiedzi na wezwanie proroka Jonasza mieszkańcy Niniwy uwierzyli Bogu, wówczas On ulitował się „nad niedolą, którą postanowił na nich sprowadzić, i nie zesłał jej" (Jon 3, 10). Łatwo zauważyć, że wszystkie przytoczone przypadki odnoszą się do człowieka uwikłanego w grzech, co do którego Bogu zależy przede wszystkim „na tym, by się nawrócił i żył" (Ez 18, 23), wskutek czego konkretne działania zbawcze Boga, z woli Jego samego, są uzależnione od woli człowieka.

To uzależnienie widać jeszcze wyraźniej w Nowym Testamencie, np. w związku z zawaleniem się wieży w Siloam, kiedy Jezus upomina: „Jeśli się nie nawrócicie, wszyscy tak samo zginiecie" (Łk 13, 4). Zresztą swą publiczną działalność zaczyna On właśnie od wezwania: „Czas się wypełnił i bliskie jest królestwo Boże. Nawracajcie się i wierzcie w Ewangelię!" (Mk 1, 15). Słusznie więc Katechizm Kościoła katolickiego podkreśla, że chrześcijańska modlitwa prośby „skupia się na pragnieniu i poszukiwaniu Królestwa, które przychodzi, zgodnie z nauczaniem Jezusa" (KKK 2632), czego szczególnym wyrazem jest modlitwa Ojcze nasz (Mt 6, 10; Łk 11, 2; por. Mt 6, 33; Łk 11, 13). Pierwszym, który pragnie i poszukuje Królestwa Bożego na ziemi, jest sam Jezus Chrystus, dlatego też Jego Ojciec zawsze Go wysłuchuje (por. J 11, 42). Natomiast w nawiązaniu do modlitwy w Ogrojcu wydaje się, że na wołanie jedynego Syna „Abba, Ojcze (...), zabierz ten 
kielich ode Mnie" odpowiedzią było milczenie; zdaje się, że On nie został wysłuchany. W istocie jednak odpowiedź została dana, choć inna od oczekiwanej po ludzku, ponieważ „został wysłuchany dzięki swej uległości (...), stał się sprawcą zbawienia wiecznego (...), nazwany przez Boga kapłanem na wzór Melchizedeka" (Hbr 5, 7. 9n). Oznacza to, że wysłuchanie próśb ludzkich inaczej wygląda z perspektywy człowieka, a inaczej z perspektywy Boga samego.

Na podstawie przytoczonych danych objawienia Bożego możemy wyprowadzić wniosek, że nasza modlitwa prośby: „Przyjdź królestwo Twoje” (Mt 6, 10), jest włączeniem ludzkiej perspektywy w Bożą perspektywę, która ostatecznie jest perspektywą „zbawienia wiecznego” dla każdego człowieka. W aktualnym nauczaniu Kościoła zawartym w jego Katechizmie prawda ta wyrażona jest za pomocą pojęcia współdziałania. Troska o Królestwo Boże jest zatem współdziałaniem „z posłaniem Chrystusa i Ducha Świętego, które jest teraz posłaniem Kościoła, jest przedmiotem modlitwy wspólnoty apostolskiej (por.Dz 6, 6; 13, 3)" (KKK 2632). W konsekwencji nie ma znaczenia werbalny aspekt modlitwy prośby (wołanie „Panie, Panie”), ale szczere pragnienie wypełnienia woli Ojca (por. Mt 7, 21). Chrystus wzywa więc swoich uczniów, „aby tę troskę o współdziałanie z zamysłem Bożym zanosili w swojej modlitwie (por. Mt 9, 38; Łk 10, 2; J 4, 34)" (KKK 2611). Zatem uczestnicząc w zbawczej miłości Boga, możemy się modlić w każdej sytuacji (por. Jk 1, 5-8; Ef 5, 20; Flp 4, 6-7; Kol 3, 16-17; 1 Tes 5, 1718) i „każda potrzeba może stać się przedmiotem prośby” (KKK 2633). 
Wspomniane wyżej dwa główne aspekty modlitwy prośby (błagalnej), czyli starotestamentalna możliwość zmiany Bożych zamiarów oraz nowotestamentalna skuteczność modlitw zanoszonych w jedności z Chrystusem, rodzi pytanie o sposób realizacji odwiecznego planu zbawienia, o istnieniu którego mówi św. Paweł w Liście do Efezjan. Jemu to bowiem „została dana ta łaska: ogłosić poganom (...), czym jest wykonanie tajemniczego planu (†் oikovouía

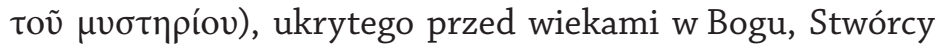
wszechrzeczy” (Ef 3, 9), a który jest realizowany „zgodnie

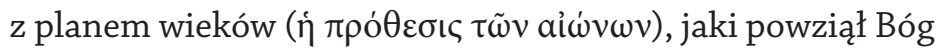
w Chrystusie Jezusie, Panu naszym" (Ef 3, 11). Ten właśnie plan i jego realizację w języku teologicznym nazywamy Opatrznością Bożą w aspekcie dziejozbawczym.

\section{Powszechność Opatrzności Bożej}

Wspomniana wyżej troska o rozwój królestwa Bożego oraz realizacja zbawczego planu Bożego odnoszą się przede wszystkim do stworzeń rozumnych (człowieka oraz „Zwierzchności i Władz” [Ef, 3, 10]), nie obejmują natomiast pozostałych stworzeń, np. „ptaków w powietrzu”, które Ojciec nasz niebieski żywi (Mt 6, 26), ani „lilii na polu”, które On przyodziewa wspanialej niż Salomona (Mt 6, 28n). Ojcowska troska o wszystkie stworzenia (rozumne i nierozumne, o której mówi Pan Jezus w Kazaniu na Górze (Mt 6, 25-34; Łk 12, 22-31) jest najbardziej lapidarnym, religijnym ujęciem tajemnicy Opatrzności Bożej. Potrzebne jest zatem integralne i pogłębione jej ujęcie. Tradycyjny sposób 
jej pojmowania ogranicza się bowiem do porządku natury i bywa nazywany kreacyjnym ${ }^{3}$, natomiast integralne ujęcie powinno objąć także Boże działanie w świecie poprzez łaskę, a więc dzieje zbawienia, czyli - innymi słowy - powinno opisywać Bożą troskę o stworzenie i o nowe stworzenie ${ }^{4}$.

Nauka o Opatrzności Bożej w ujęciu kreacyjnym została sformułowana na Soborze Watykańskim I (1870). Na jej podstawie Katechizm Kościoła katolickiego uczy nas, że „Bożą Opatrznością nazywamy zrządzenia (dispositiones), przez które Bóg prowadzi swoje stworzenie do (...) doskonałości" (KKK 302) $)^{5}$. To prowadzenie jest konieczne, ponieważ stworzenie „nie wyszło całkowicie wykończone z rąk Stwórcy. Jest ono stworzone «w drodze» (in statu viae) do ostatecznej doskonałości, którą ma dopiero osiągnąć i do której Bóg je przeznaczył" (KKK 302). Dalej, cytując wspomniany Sobór, Katechizm uczy: „wszystko zaś, co Bóg stworzył, zachowuje swoją Opatrznością i wszystkim rządzi, «sięgając potężnie od krańca do krańca i władając wszystkim z dobrocią» (Mdr 8, 1)" (za: KKK 302; DS 3003). W sumie cała katechizmowa nauka o Opatrzności Bożej (KKK 302314) opiera się na wspomnianym orzeczeniu Soboru Watykańskiego I. Z kolei soborowa nauka nawiązuje do św. Tomasza z Akwinu, który w Opatrzności Bożej wyróżnia

${ }^{3}$ Cz. Bartnik, Dogmatyka katolicka, t. 1, Lublin 2000, s. 145.

4 Takie właśnie ujęcie zostało zaprezentowane w: J.D. Szczurek, Opatrzność Boża i jej zbawcza celowość, Kraków 2013.

5 „Divinam apellamus providentiam dispositiones per quas Deus Suam creationem in hanc ducit perfectionem", Catechismus Catholicae Ecclesiae. Editio typica, Città del Vaticano 1997, n. 302 (s. 89). 
dwa aspekty ${ }^{6}$ : plan rzeczy (ratio ordinis rerum) i jego realizację (executio ordinis rerum), innymi słowy - rządy (gubernatio). Rządy Boga nad światem polegają zaś m.in. na tym, że daje On bytom przez siebie stworzonym zdolność sprawiania skutków zgodnie z ich naturą (tak jak np. król daje władzę swoim ministrom) ${ }^{7}$. Rządzenie światem niekoniecznie więc musi być wykonywane wprost przez Opatrzność Bożą. Tomasz wyjaśnia to w ten sposób, że bytami niższymi Bóg rządzi przy pomocy wyższych, ponieważ w swej dobroci daje On swoim stworzeniom zdolność, a także i godność bycia przyczyną dla innych ${ }^{8}$. W ten sposób Tomasz wprowadza rozróżnienie na przyczynowość pierwotną (Bożą, niestworzoną) i wtórną (stworzoną). To rozróżnienie jest podstawą nauki o uczestnictwie człowieka (i innych stworzeń) w działaniach Opatrzności Bożej ${ }^{9}$.

Naukę o Opatrzności Bożej szerzej pojętą, a więc obejmującą także dzieje zbawienia, również znajdujemy we wspomnianym Katechizmie. W streszczeniu nauki o Opatrzności Bożej Katechizm stwierdza, że „Opatrzność Boża oznacza zrządzenia, przez które Bóg z miłością i mądrością prowadzi

${ }^{6}$ Tomasz z Akwinu, Traktat o Bogu. Summa teologii. Kwestie 1-26, tłum. G. Kurylewicz, Z. Nerczuk, M. Olszewski, Kraków 1999, s. 336 i n. (dalej: S. th.). „Ad providentiam duo pertinent: scilicet ratio ordinis rerum provisarum in finem; et executio huius ordinis, quae gubernatio dicitur", S. th. I, q. 22, a. 3.

${ }^{7}$ S. th. I, q. 22, a. 3.

${ }^{8}$ Tomasz z Akwinu, Traktat o Bogu..., s. 337. „Quia inferiora gubernat per superiora; non per defectum suae virtutis, sed propter abundantiam suae bonitatis, ut dignitatem causalitatis etiam creaturis communicet", S. th. I, q. 22, a. 3.

${ }^{9}$ Więcej na temat Opatrzności Bożej u Tomasza z Akwinu, zob. J.D. Szczurek, Opatrzność..., dz. cyt., s. 121-125. 
wszystkie stworzenia do ich ostatecznego celu" (KKK 321). To drugie katechizmowe określenie jest teologicznie bogatsze, ponieważ wskazuje na miłość Boga, Jego mądrość oraz ostateczną celowość stworzeń. Właśnie zwrócenie uwagi na miłość uświadamia nam odniesienie Opatrzności Bożej do stworzeń osobowych i jego zbawczy wymiar (por. J 3, 16n). Z kolei ogólne określenie „wszystkie stworzenia” odnosi się także do stworzeń wolnych (osobowych), czyli także do człowieka, dzięki czemu wskazuje na jego zbawienie, innymi słowy także na zbawczą celowość. Podkreślić należy użycie słowa „zrządzenie” (dispositio) zamiast soborowego „rządzi” (gubernat), co wyraźniej podkreśla mądrość i roztropność Boga w dobieraniu optymalnych rozwiązań, mniej natomiast apodyktyczność „rządów”"10.

Przytoczona nauka Kościoła pozwala wyróżnić trzy podstawowe przymioty Opatrzności Bożej: celowość, dobroć (łagodność) i powszechność. Celowość oznacza, że Opatrzność kieruje wszystkie stworzenia ku doskonałości dla nich przewidzianej i im właściwej, w przypadku stworzeń osobowych i wolnych celem jest zbawienie wieczne ${ }^{11}$. Dobroć albo łagodność oznacza, że Opatrzność kieruje stworzeniami zgodnie $\mathrm{z}$ ich naturą, a więc stworzeniami bezwolnymi przy pomocy praw natury, zaś stworzeniami wolnymi (osobowymi) - przez prawo moralne (przykazania Boże) i przez łaskę, co oznacza, że są w stanie się sprzeciwić temu prawu, a nawet wzgardzić łaską ${ }^{12}$. Wreszcie powszech-

${ }^{10}$ Por. J.D. Szczurek, Opatrzność..., dz. cyt., s. 163.

${ }^{11}$ Więcej na temat celowości w działaniach Opatrzności Bożej zob. J.D. Szczurek, Opatrzność..., dz. cyt., s. 157-162, 168-171.

12 O łagodności Opatrzności Bożej zob. J.D. Szczurek, Opatrzność..., dz. cyt., s. 221-223. 
ność oznacza, że wszystkie stworzenia bez wyjątku podlegają Opatrzności Bożej: nieożywione i ożywione, materialne i niematerialne, bezwolne i wolne, bezosobowe i osobowe - od najmniejszego do największego, od cząstki elementarnej po cały Wszechświat, od pojedynczego człowieka po całą ludzkość od początku jej istnienia aż po wieczność ${ }^{13}$. Tak szeroko rozumiana powszechność Opatrzności Bożej bywała przedmiotem wątpliwości uzasadnianych tym, że komuś tak wielkiemu jak Stwórca nie przystoi zajmować się pojedynczym wróblem, a nawet konkretnym człowiekiem... Jednak stwierdzenie Jezusa: „U was zaś nawet włosy na głowie wszystkie są policzone” (Mt 10, 30), nawet jeśli jest hiperbolą, wskazuje, że Bóg w swej Opatrzności rzeczywiście zajmuje się każdym człowiekiem z osobna, dlatego „każdy, kto prosi, otrzymuje" (Mt 7, 8). Jeśli jednak uświadomimy sobie, że obecnie na świecie żyje 7,5 mld ludzi, wydaje się trudne do pojęcia, jak można zajmować się każdą osobą indywidualnie. Na tym właśnie m.in. polega tajemnica Opatrzności Bożej.

Zarówno Tomaszowy „plan świata” (ratio mundi), jak i Pawłowy „tajemniczy plan [zbawienia]” (†̇ olkovouía toṽ

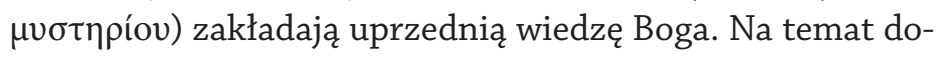
skonałości Bożej wiedzy Sobór Watykański I uczy, że „jeden Bóg prawdziwy i żywy” jest „nieskończony (...) pod względem umysłu"14. Tak określona doskonałość umysłu Bożego odnosi się również do Opatrzności Bożej i oznacza wszechwiedzę, której przedmiotem jest cała rzeczywistość. Przez

13 Tak opisany przymiot Opatrzności Bożej zwykło się nazywać Opatrznością ogólną, por. Cz. Bartnik, Dogmatyka..., t. 1, dz. cyt., s. 145; J.D. Szczurek, Opatrzność..., dz. cyt., s. 186-188.

${ }^{14}$ DSP 4, s. 893; DS 3001. 
rzeczywistość zaś rozumiemy wszystko, co kiedykolwiek się dokonało w przeszłości, aktualnie się dzieje i kiedykolwiek faktycznie się dokona w świecie duchów czystych, we wszechświecie i w dziejach ludzkości. Następnie, posługując się tekstem z Listu do Hebrajczyków, Sobór dookreśla zakres wszechwiedzy Boga: „wszystko bowiem «odkryte i odsłonięte jest przed oczami» [Hbr 4, 13] Jego, także to, co nastąpi w przyszłości wskutek wolnego działania stworzeń"15. Szczególną cechą tak opisanej wszechwiedzy jest jej pozaczasowość. Nie jest ona bowiem rezultatem procesu poznawczego w stosunku do istniejącej już rzeczywistości, jak to jest w przypadku ludzkiej wiedzy, ale jest wiedzą uprzednią, stwórczą, wynikającą z aktu stwórczego, czyli wiedzą o tym, co zostało bądź zostanie stworzone. Krótko mówiąc, Stwórca jest świadom nie tylko tego, że stwarza, ale także tego, co stwarza i jak stwarza, a więc także jaka jest natura wolności, którą obdarza niektóre ze swoich stworzeń. W konsekwencji również wiedza o rzeczach przyszłych, czyli Boże przewidywanie, jest diametralnie różna od przewidywania ludzkiego, które jest możliwe dzięki znajomości praw natury i przebiegu procesów przez nie kierowanych. Ludzkie przewidywanie jest zwykle obarczone błędem. Boże przewidywanie natomiast nie jest przewidywaniem w sensie właściwym, ale jest wiedzą oglądową (scientia visionis), dzięki której Bóg „widzi” (w odwiecznym „teraz”)16 wszystkie następujące po sobie wydarzenia i związki między nimi, w porządku ich urzeczywistniania się, jeszcze zanim się

${ }^{15}$ "Omnia enim nuda et aperta sunt oculis eius, ea etiam, quae libera creaturarum actione futura sunt", DSP 4, s. 894, w. 5-8; DS 3003. Tekst polski: DSP 4, s. 895.

${ }^{16}$ Por. Cz. Bartnik, Dogmatyka..., t. 1, dz. cyt., s. 132. 
dokonają ${ }^{17}$. W konsekwencji oznacza to, że dla tak opisanej wszechwiedzy nie ma „niespodzianek”, Opatrzności Bożej nic nie jest w stanie zaskoczyć, nie potrzebuje więc niczego zmieniać w swoich planach, jest po prostu niezmienna.

W tym kontekście pojawia się możliwość odpowiedzi na główne nasze pytanie: czy wobec tego jakakolwiek modlitwa prośby (błagalna) może cokolwiek zmienić w wykonywaniu planów Opatrzności Bożej? Przytoczone bowiem wcześniej świadectwa biblijne (np. przypadek Niniwy) sugerują możliwość zmian. Jak to wyjaśnić? Odpowiedź daje nam św. Tomasz z Akwinu, zwracając uwagę na kilka aspektów. Najpierw zauważa, że zanosimy prośby do Boga nie po, aby zmieniać odwieczne zrządzenia Jego Opatrzności, ale po to, aby otrzymać potrzebne dary ${ }^{18}$. Poza tym, dlaczego dobry Bóg nie miałby okazywać swej dobroci tym, którzy Go proszą, skoro ludzie wysłuchują jedni drugich? Przecież Zbawiciel wprost powiedział: „każdy, kto prosi, otrzymuje; kto szuka, znajduje; a kołaczącemu otworzą" (Mt 7, 8) ${ }^{19}$. Ponadto - przypomina Akwinata - Bóg kocha ludzi, więc dlaczego miałby nie spełniać ich pragnien, skoro ludzie wspomagają swoich przyjaciót? ${ }^{20}$ Te odpowiedzi z egzysten-

${ }^{17}$ Por. L. Ott, Grundriss der katholischen Dogmatik, Freiburg-BaselWien 1981, wyd. 10, s. 48.

${ }^{18}$ Por. Summa c. gent. III 95. Tekst polski: Tomasz z Akwinu, Summa contra gentiles. Prawda wiary chrześcijańskiej wdyskusji z poganami, innowiercami i błądzącymi, t. 3, tłum. Z. Włodek, W. Zega, Poznań 2009, s. 282 i n.

${ }^{19}$ Por. Summa c. gent. III 95; Tomasz z Akwinu, Summa contra gentiles..., dz. cyt., s. 284.

${ }^{20}$ Por. Summa c. gent. III 95; Tomasz z Akwinu, Summa contra gentiles..., dz. cyt., s. 284 i n.

48 . Ks. prof. dr hab. Jan Daniel Szczurek 
cjalnego punktu widzenia są zadowalające, ale nie wyjaśniają samej istoty problemu.

Dopiero w polemice z poglądami stoików Akwinata wyjaśnia go bardzo prosto, formułując przy tym niezwykle ważną zasadę: modlitwy „mają wartość nie dlatego, jakoby zmieniały odwiecznie ustanowiony porządek, lecz dlatego, że one same należą do tego porządku. Nic zaś nie przeszkadza, by w wyniku modlitw uległ zmianie szczegółowy skutek jakiejś niższej przyczyny za sprawą Boga, który przewyższa wszystkie przyczyny"21. Tak sformułowana zasada oznacza, że św. Tomasz nie wyklucza rzeczywistej zmiany po stronie Opatrzności Bożej, ale jeśli nawet miałaby się dokonać na poziomie niższych przyczyn, to i tak jest uprzednio przez Nią przewidziana ${ }^{22}$.

\section{Opatrzność Boża w życiu bł. Marii Angeli}

Czasy, w których żyła bł. Maria Angela, naznaczone były m.in. dyskusjami na temat Opatrzności Bożej w polemice z deizmem. Zauważmy, że Sobór Watykański I sformułował naukę o Opatrzności Bożej właśnie w roku, w którym ona przeniosła się z domu przy ul. Mikołajskiej w Krakowie do nowo wybudowanego klasztoru przy ul. Smoleńsk (20 stycz-

${ }^{21}$ „Valent igitur orationes non quasiordinem aeternae dispositionis immutantes, sed quasi sub tali ordine et ipsae existentes. Nihil autem prohibet per orationum efficaciam aliquem particularm ordinem alicuius inferioris causae immutari, Deo faciente, qui omnes supergreditur causas" (Summa c. gent. III 96; Tomasz z Akwinu, Summa contra gentiles..., dz. cyt., s. 289).

${ }^{22}$ W kwestii niezmienności Opatrzności Bożej i sensu modlitwy prośby zob. J.D. Szczurek, Opatrzność..., dz. cyt., s. 171-177. 
nia 1870). W tym czasie jej choroba zaczyna się coraz bardziej nasilać, co sprawia, że usuwa się w cień i oddaje się modlitwie i apostolstwu cierpienia.

W jej tekstach, które zostały opublikowane, jest kilka wypowiedzi związanych z tajemnicą Opatrzności Bożej. W Radach duchowych dla s. M. Bogdany ([Warszawa] 18 lipca 1860) bł. Maria Angela przypomina konieczność zaufania Bożej opiece, bo dzieje zbawienia potwierdzają ojcowską troskę Boga: „Czegóż mamy się obawiać, mając takiego Ojca, bez którego woli i jeden włos z głowy nam nie spadnie? Dziwić się wypada, że będąc dziećmi takiego Ojca, możemy o co innego się troszczyć jak o to, abyśmy Go doskonale kochali i wiernie Mu służyli (...). I ty także przypomnij sobie ten czas utrapienia (...). Bóg cię dotychczas nie opuścił. Dlaczegóż miałby cię teraz opuścić, kiedy więcej jak przedtem pragniesz Mu się zupełnie oddać"23. Na szczególne podkreślenie zasługuje tu pragnienie doskonalszej miłości Boga i wiernego służenia $\mathrm{Mu}$, które jest wyrazem osobistego zaangażowania w sprawy królestwa Bożego i ofiary z własnego życia, co jest szczególną formą modlitwy niewerbalnej (wspomnianej wyżej).

Później, w Liście do s. Marii Jadwigi ([Warszawa], 28 sierpnia [1863]) podkreśla wyjątkowość opieki Bożej i skuteczność modlitwy (werbalnej) połączonej z osobistym poświęceniem: „Wiem z opowiadania M. Elżbiety i wystawiam sobie, jakie Wasze położenie jest trudne, wiele macie pracy, na wiele niebezpieczeństw jesteście narażone. Prawdziwie podziwiać trzeba tę opiekę Bożą nad Wami, że się dotychczas nic złego nie stało (...). Teraz więcej jak kiedykolwiek

${ }^{23}$ M.A. Truszkowska, Wybór pism, t. 3, Rzym 1982, s. 140-141. 
za Was się modlimy (...). Wasza modlitwa skuteczniejsza jak nasza, bo połączona nie tylko z dobrymi uczynkami, ale [z] cnotami heroicznymi. O tak, śmiało można powiedzieć, że wypełniacie cnoty heroiczne $\mathrm{w}$ tym posłuszeństwie, w takim zaparciu i poświęceniu"24.

Zaufanie Bożej Opatrzności widać szczególnie wyraźnie, gdy po odmowie wspierania sióstr przez margrabię Wielopolskiego tak pisała w Liście do s. Marii Jadwigi do Chrobrza (Warszawa, 22 kwietnia 1864), nawiązując do przykładu św. Franciszka z Asyżu: „Lękać się zaufać Opatrzności Boskiej byłoby to niegodne każdej chrześcijanki, a podłością dla córki prawdziwej św. o. Franciszka. Ja mam nadzieję, że Wy, moje najmilsze, będziecie korzystać z tej sposobności okazania, że pojmujecie ducha naszego Zakonu (...). Ja myślę, że to wszystko nie do upadku, ale do podniesienia ducha wielce Wam pomoże"25. W tej sytuacji radziła s. Marii Jadwidze, aby zdała się na Opatrzność Bożą i prosiła chłopów w Chrobrzu o jałmużnę taką, na jaką ich stać (bez stałych zobowiązań) ${ }^{26}$.

W Liście do s. Marii Izabeli [Kraków 1867], przełożonej sióstr klauzurowych w Łowiczu, przypominała: „P. Bóg w każdej chwili okazuje, jak cudownie nad Wami czuwa i do końca nie przestanie się Wami opiekować. Miła Mu jest ofiara, jakąście Mu same z siebie złożyły, tylko wytrwajcie do końca w tym duchu ofiary, tylko nie zrażajcie się przeciwnościami, nie upadajcie na duchu, ale owszem niech wszystkie przeciwności będą dla Was bodźcem do coraz większej gorli-

\footnotetext{
${ }^{24}$ M.A. Truszkowska, Wybór pism, t. 1, Rzym 1977, s. 129 i n.

${ }^{25}$ M.A. Truszkowska, Wybór pism, t. 1, dz. cyt., s. 154.

${ }^{26}$ M.A. Truszkowska, Wybór pism, t. 1, dz. cyt., s. 153.
} 
wości i wierności w służbie Pańskiej”27. W dalszej części tego listu wyraża radość z opieki Bożej, jakiej siostry doznają w chwili próby: „Cieszę się bardzo, że P. Jezus tak cudownie opatruje Wasze potrzeby, bo przy tylu chorych brak byłby bardzo przykry. A widać, że P. Jezus krzyżem choroby przyciskać nas teraz zechce, bo i u nas prawie wszystkie chore"28.

Przytoczone teksty założycielki Zgromadzenia Sióstr Felicjanek świadczą o jej głębokiej i prostej wierze w Opatrzność Bożą. Prostej dlatego, że pojmuje ją biblijnie (a nie filozoficznie) jako opiekę Bożą wobec tych, którzy z oddaniem pełnią wolę Bożą. Biblijne odniesienia widać w nawiązaniu do włosów na głowie (Mt 10, 30) we wspomnianych Radach duchowych czy do ptaków na polu (Mt 6, 26) ${ }^{29}$ albo też do posłania apostołów bez trzosa, torby i sandałów $(Ł k ~ 22,35)^{30}$. Tę wiarę pragnęła zaszczepić swoim duchowym córkom, podtrzymując je na duchu i uświadamiając im, że Pan Jezus zsyła wiele różnych utrapień, bo mają „być opoką, na której mają się opierać przyszłe pokolenia, a im więcej bałwany biją w opokę, tym więcej ją czynią twardą i niewzruszoną. Więc pamiętajcie, moje najmilsze, że to wszystko, co Was spotyka, nie tylko dla dobra Waszego, ale i dla innych dusz, które po was nastąpią, jest pożyteczne"31.

Faktycznie, siostry z czasów Marii Angeli stały się taką opoką dla przyszłych pokoleń. Za przykład szczególnego oddania się Opatrzności Bożej służy Dom Opatrzności Bożej

${ }^{27}$ M.A. Truszkowska, Wybór pism, t. 1, dz. cyt., s. 73 i n.

${ }^{28}$ M.A. Truszkowska, Wybór pism, t. 1, dz. cyt., s. 75 i n.

${ }^{29}$ M.A. Truszkowska, Wybór pism, t. 1, dz. cyt., s. 153.

${ }^{30}$ M.A. Truszkowska, Wybór pism, t. 3, dz. cyt., s. 141.

${ }^{31}$ M.A. Truszkowska, Wybór pism, t. 1, dz. cyt., s. 73 i n. (List do s. Marii Izabeli [Kraków 1867]).

52. Ks. prof. dr hab. Jan Daniel Szczurek 
w Iwoniczu (dziś archidiecezja przemyska), funkcjonujący od 1883 roku do dziś. Jest to wprawdzie jedyny dom pod takim wezwaniem w prowincji krakowskiej, ale niewątpliwie szczególny. Jego ciekawe i trudne dzieje są opisane w Leksykonie domów prowincji krakowskiej sióstr felicja$n^{32}$. Dom ten powstał z inicjatywy ówczesnego proboszcza iwonickiego ks. Antoniego Podgórskiego (1848-1912) ${ }^{33}$, który zatroskany o dobro powierzonej mu cząstki ludu Bożego zainicjował „różne dzieła charytatywne w celu podniesienia poziomu oświatowego, kulturalnego, a zwłaszcza moralnego ludności, mimo braku materialnego zaplecza, ufając bezgranicznie w pomoc Bożej Opatrzności”34. To zaufanie podzielały oczywiście również siostry, skoro zgodziły się podjąć prowadzenie takiego domu bez stałego uposażenia. Dzięki temu powstały w Iwoniczu sierociniec i szkoła ludowa żeńska. W dwa lata później (1885) przełożona generalna matka M. Magdalena Borowska tak pisała o siostrach w tym domu: „Widoczne błogosławieństwo towarzyszy ich pracom - szczególnie podziwiać należy zmianę serc tych wszystkich, którzy byli najprzeciwniejsi sprowadzeniu Sióstr. Dom wzięty bez żadnych funduszów, a Siostrom na niczym nie zbywa i długu nie mają" 35 . Później, po latach gdy doszło do zamiany sierocińca (ówczesnego domu dziecka) na zakład specjalny dla dzieci głęboko upośledzonych

${ }^{32}$ M.P. Lenart, Prowincja Krakowska Niepokalanego Serca Najświętszej Maryi Panny Zgromadzenia Sióstr Felicjanek. Leksykon domów (1861-1981). Bełz - Kozłów, t. 2/1, Kraków 1999, s. 287-333.

${ }^{33}$ Więcej o ks. Podgórskim zob. M.P. Lenart, Prowincja Krakowska..., dz. cyt., s. 312-313.

${ }^{34}$ M.P. Lenart, Prowincja Krakowska..., dz. cyt., s. 288.

${ }^{35}$ M.P. Lenart, Prowincja Krakowska..., dz. cyt., s. 290. 
(1952) praca sióstr zmieniła się radykalnie, ponieważ przybywające tam dzieci miały wysoki stopień niepełnosprawności umysłowej, a często równocześnie fizycznej, i wymagały wiele troski, niektóre nawet takiej jak niemowlęta ${ }^{36}$. O zaangażowaniu sióstr z podziwem pisze (10 czerwca 1954) s. M. Bonawentura Zarzycka, radna prowincjalna: „Praca Sióstr nad tymi najnieszczęśliwszymi w społeczeństwie jest pełna zaparcia i poświęcenia. Bez specjalnej pomocy łaski Bożej jest to praca nie do pomyślenia"37. To świadectwo s. M. Bonawentury potwierdza wielkie zaufanie Opatrzności Bożej, którego uczyła matka Maria Angela, a czego wyrazem jest wyżej cytowany fragment jej listu do s. Marii Izabeli (o współdziałaniu z łaską Opatrzności przez osobistą ofiarę i modlitwę).

Podsumowując, trzeba z naciskiem podkreślić, że modlitwa prośby połączona z osobistym poświęceniem się Bogu w Trójcy Świętej Jedynemu, w Katechizmie opisana jako walka, jest w stanie „zmienić” Boże zamiary, czyli faktycznie współdziałać z Opatrznością Bożą. Wszystkie bowiem modlitwy ludzi są przewidziane przez Nią i są wpisane w Jej plany, stanowią ich integralną część. Innymi słowy, Opatrzność przewiduje, czy dane wydarzenie dokona się w następstwie takich próśb, czy też w następstwie ich zaniechania, czy też z ich pominięciem. O tym, że takie modlitwy rzeczywiście

\footnotetext{
${ }^{36}$ M.P. Lenart, Prowincja Krakowska..., dz. cyt., s. 305.

${ }^{37}$ M.P. Lenart, Prowincja Krakowska..., dz. cyt., s. 307.
} 
mają wpływ na działanie Opatrzności Bożej, świadczy przykład bł. Marii Angeli, a dowodem na to jest błogosławieństwo Boże w konkretnych sytuacjach, pozwalające jej dziełu rozwijać się pomimo przeróżnych piętrzących się trudności. Siłą do ich przezwyciężania jest wiara, że osiągnąć można „wszystko przez Serce Maryi na cześć Przenajświętszego Sakramentu"38.

${ }^{38}$ Dewiza Sióstr Felicjanek zainicjowana przez bł. Marię Angelę, używana w tej postaci od czasu, gdy w 1881 roku zgromadzenie otrzymało przywilej całodziennego, nieustannego wystawienia Najświętszego Sakramentu (na podstawie Ofiarowania się Sercu Maryi z 1874 roku, M.A. Truszkowska, Wybór pism, t. 3, dz. cyt., s. 15 i n.). 